\title{
An Exploration of Private Sector Financing of Higher Education in the Philippines and Its Policy Implications for India
}

\author{
Kishore M.Joshi
}

\section{Introduction}

Today majority of the governments in developing countries are under great pressure to restrain public spending on higher education. The structural adjustment programs favoured by the IMF and World Bank emphasize reduction in public expenditure, largely because of budget deficits and external debts. It is this state of affairs that has prompted many countries to search for alternative sources other than the public treasury. In the context of higher education, advocacy of private financing has become increasingly common, while the measures for effective cost recovery and private investment too have emerged as an accepted tool. But there are already a few selected developing countries where the role of private sector financing in higher education has been strong for decades. One of them and foremost among these is the Philippines where private higher education has been an important and accepted part of national policy since preindependence.

Higher education in the Philippines is distinctive in many aspects, and among all its features, the role of the private sector is the most interesting to know. The Philippine university system has been modelled after that of the United States' model, despite the country's vastly different cultural, political and economic realities (Smolicz, 2002).

Among its other features, the Philippines continues to have one of the shortest pre-entry systems ${ }^{1}$ in the world, resulting in younger and less educated students in the system when compared to other countries in Asia. The transition rate between secondary and higher education is about 90 percent, which is exceptionally high, owing to the strong demand for higher education among parents for their children. The gross enrolment ratio/participation ratio is about 23 percent.

Higher education in the Philippines is also overwhelmingly private that it is conventionally discussed in terms of more meaningful subdivisions: proprietary, sectarian, and non-profit ${ }^{2}$. 
The present study of Philippine privately financed and managed higher education tries to look at the prominent features of Philippine private higher education through its history, and to examine the issues of equity, efficiency and quality in order to bring out some policy implications for the emerging private higher education system in India.

\section{Private Institutions and Their Characteristics}

The private higher education sector of the Philippines is proportionally larger than that of any major country. Nearly 88 percent of the institutions are privately owned and managed without subsidies from the government, and 67 percent of all students are enrolled in private higher education institutions. The enrolment in various programs clearly reflects that higher education in the Philippines is determined largely by market forces and the dominant private higher education institutions are there in response to student demand for different programs (Tan, 1995).

The trend, however, shows a decline in the share of private education in terms of total enrolments, as the public sector has grown. The number of private higher education institutions has increased at an average annual rate of about 3 percent since 1995.

One of the most basic features of mass private higher education in the Philippines from its period of development till the present is an extreme reliance upon tuition revenues, even though they depend predominantly upon a student client that is by no means healthy. Dependence on revenues from tuition and other fees ranges from a high of 97 percent to 82 percent. The income from other private sources does not contribute significantly to total income. Personal services including salaries and wages are the largest component of recurring costs, and it ranges from 41 to 84 percent across various institutions. The maintenance and operating costs (inclusive of general and administrative overhead expenses) range between 11 to 46 percent.

The private institutions are concentrated and dispersed. There are large clusters of private institutions in the cities, this means they are still founded on commercial bases (Balmores, 1990). This has led to pronounced concentration of private institutions in urban areas such as Metro Manila, Central Luzon, Southern Tagalog and Western Visayas .

The remarkable access to higher education nevertheless has its negative aspects. The private institutions also have a wide diversity of standards of education, from the highest to the lowest. While only selected private institutions are comparable to the best of the state institutions (University of Philippines), the bulk of the additional student places are of inferior quality.

\section{History of Private Higher Education in the Philippines}


The historical origin of higher education in the Philippines can be traced in its proper form to the Spanish regime. The educational policies initiated by the Spanish kings were carried out by the religious orders that came to the Philippines. Higher education during the Spanish regime was represented by the University of Santo Tomas (UST) and for over two centuries the UST remained the source of manpower training (Bazaco, 1939).

With the inception of the American regime (1898-1946) a radically different school system was set up. The Americans transplanted their own kind of education system in the Philippines (its new Asian colony) because of their non-familiarity with Philippine socio-economic and cultural problems. American history, geography and literature became major curricular offerings. On the one hand, the government was evolving the public school system, and on the other hand Filipino leaders and educators ${ }^{3}$ realized the need to establish private institutions in order to provide an education distinctively Filipino in orientation.

The lifting of clerical control over education at a time when the educational horizons of Filipinos were rapidly widening led to diverse public initiatives in founding institutions. Almost all of these ventures began as elementary or secondary schools and subsequently developed into colleges or universities. Along with the public institutions set up by Americans, private individuals, with an objective to preserve the Filipino culture, established many private Filipino centres of learning ${ }^{4}$ (Hayden, 1942). With the approval of the constitution of the commonwealth in 1935, a more clear-cut policy concerning the relations between the government and the private schools and colleges came about. The constitution specifically provided that all educational institutions should be subject to regulation and supervision by the state. The Office of Private Education, headed by a Director, was established.

In 1941, with the outbreak of the World War II and for more than three years of the Japanese occupation of the country, there was no attempt by the Japanese government to foster the growth of educational institutions. Instead, they wrecked the towns and cities, including educational establishments. They stampeded into schools, colleges and universities as soon as hostilities ended on September 2, 1945 (Isidro and Ramos, 1973).

Thus, both physically and morally, the nation was prostrate after the Japanese regime. To rebuild the economy and restore educational institutions, Filipinos sought and received United States assistance. The contribution of Filipino private educators also began establishing new private universities and colleges ${ }^{5}$.

The simultaneous features in the post independence period i.e., increased private demand for higher education and scarce resources of the government, led to the self momentum of the higher education sector towards the private sector. The economic reconstruction remained the priority of the state; the state hardly considered the education sector as a part of its new order. Inevitably, 
higher education fell into the hands of the private sector and it began taking shape with private resources.

\section{Equity}

There is ample evidence that some groups in developing countries have better access to higher education than others, but the factors determining access vary across countries or within regions of a country. In case of the Philippines, one can find considerable differences in higher education participation of individuals depending on economic background, sex, and urban and rural areas. The economic background has been a major factor influencing access and it is necessary to understand the economic aspects in considering the equity issue.

The Family Income and Expenditure Survey (FIES) of 1997 clearly reflected that the richest 3 percent of the families possessed as much income as the entire lower 50 percent of families on the income scale. The 2000 FIES suggests that the incidence of poverty actually rose slightly (World Bank, 2002). In addition, there were no reductions in the percentage of population living on less than US\$1 per day (2-13 percent) or in the percentage living on less than US\$2 per day (between 45 and 46 percent) between 1997 and 2000 ${ }^{6}$. Although the 2003 FIES shows some improvements, inter and intra provincial differences still remain a matter of concern. The opportunities for economic development will naturally be asymmetrical and skewed to those who have access to education, which is a function of means.

In a country like the Philippines, where private enrolments and full cost pricing predominate, the distribution of income may impinge further on the allocation of resources in education. This is true when capital markets for human capital borrowing are highly imperfect. The distributive consequences too are of substantial interest. A study of student financial aid in the Philippines (Hauptam and Cao, 2001), covering scholarships, grants and loans, indicates that the 'non-poor' have both better access to and higher completion rates in higher education programs than those classified as 'poor'. It is this unfortunate feature that makes the objective of equity even weaker.

The paradox of gender equity in the Philippines is that the enrolment of females in total enrolment is much higher than that of males. The problem is sustaining the male students who have a high drop out rate.

The current higher education system of the Philippines, both public and private, has adopted an entrance program to measure academic proficiency for immediate post secondary education admission. The outcome is generally skewed in favour of the affluent (Ravalo, 2002). This skewed result can be attributed to the better primary and secondary school education among the affluent, which in the later stage of post secondary higher education, makes them better equipped for the academic rigors of getting into better institutions and of degree completion. 
Higher education, especially private higher education, is expensive, but a wide range of prices exists. The great majority of poor families are able to afford and demand inexpensive education (Valisno, 2000). These are poor quality programs and with low returns too. A study (Haas, 1998) has revealed that when compared with public sector tuition, on average, private higher education costs seven times more in non-exclusive private institutions and 21 times as much in exclusive private higher education institutions. The situation in the post 2000 period has not changed drastically.

The government extends a wide range of financial support in the form of scholarships, grants and student loans, which also gets extended to private institutions. Manasan (1998) observed that 70 percent of higher education scholarships were awarded to the non-poor, although the requirements for government student aid clearly state that recipients should be needy. This clearly reveals that unfortunately there has been no systematic evaluation of the various student loan programs of the government.

Although majority of the private schools extend scholarships to more than 5 percent of their enrolees and spend more than 5 percent of their income, a closer look discloses that it does not serve the purpose of equity and access on a larger scale among different social sectors and the different regions. But few private sectarian institutions are making appreciable efforts to increase access and equity ${ }^{7}$. Private corporate foundations and other private donors also contribute to support higher education in the Philippines.

One can conclude that the issue of equity and access in the Philippines are affected by the quality of institutions, geographical location, high tuition and other fees, disparity in social class, varied educational background, survival rates, and other factors.

\section{Efficiency}

The term 'efficiency' describes the relationship between inputs and outputs. In analysing education, both 'internal and external efficiency' ${ }^{8}$ must be taken into account. The benefits of higher education investments derive largely from skill formation ${ }^{9}$. So the investments in higher education must respond to the economy's demand for workers by level and type of education. But in the case of the Philippines, the failure of the state in framing an effective precise policy for higher education along with slow industrial development force the private sector to follow the programs influenced by the foreign labour market for immigrants ${ }^{10}$.

It is imperative to know the cost and benefits of acquiring the skills in context of varied endowments of education/training. And for this the rate of returns has been a crucial tool ${ }^{11}$. The other method, namely manpower planning and forecasting method is not considered here because of the reiterated strong doubts its accuracy and reliability reflected in various studies 
(Snodgrass and Sen, 1979; Jolly and Colclough, 1972; Ahamad and Blaug, 1973), and also largely due to non availability of such manpower forecasted data for the Philippines in the past decade.

The Philippine higher educational system is characterized by high attendance rates, implying that unlike other developing countries, there is widespread private interest in educational investments. This feature reflects a rate of return that is more akin to those of advanced countries. The Philippine rate of return has always exhibited an uncommon behaviour; inspite of the Philippines being categorised as a developing country, its rate of return is more comparable to that of a more developed country ${ }^{12}$, a phenomenon in an educational system with high enrolment rate (Psacharopoulos and Patrinos, 2002: Paqueo and Tan, 1989; Orbeta, 2001). The rate of return estimates in general have been relatively stable during the last few years, though they have mostly increased over the eight year period and fallen for the last five years. The private and social rates of return have been around 12 percent and 11 percent respectively.

In considering the efficiency issues it is also necessary to look at the cost related and nature of student flow issues. The unit cost in private institutions differs too much from public institutions. The cost per student in private institutions is almost one-third of those in public institutions. The reasons for this difference is that majority of the private institutions concentrate on low cost professional programs, the enrolments in private institutions are very large, lack of research activities and over utilization of teaching personnel. Inspite of these, one can definitely conclude that private institutions are cost effective in a real sense.

The current survival rate is around 67 percent and graduation rate is about 47 percent. It means that completion rate is low. Meanwhile, the drop out rate is another issue, and this appears to be severe in private institutions. The reason for the difference undoubtedly is the higher burden of full-cost pricing (tuition) in private higher education institutions along with the nature of transition rate from secondary level to higher education.

The enrolment data of private higher education institutions shows that the flow has been towards the professional orientation. But available data indicate that the type and quality of higher education graduates do not match the manpower requirements of an industrializing economy (CHED, 2001). There is a mismatch between degrees and employment. Unemployment rate is around 11 percent and in case of educated unemployment the situation is alarming. The Philippine labour force data shows that those with higher levels of education have higher unemployment rates. The graduates from accredited and prestigious institutions ${ }^{13}$ experience higher rates of employment and incomes. Overall employment picture shows that graduates of private institutions are far better off than those from public institutions (Arcelo, 2001).

\section{Quality}


The performance of higher education institutions is a growing concern. The pressure for quality assurance poses a major challenge for Philippine higher education as in the case of many developing countries including India. The problem of quality becomes specially pressing in higher education where the government has allowed the private sector to dominate; thus, the government finds itself in the paradoxical position of trying to set up and enforce standards in an area which it is unwilling to enter (Lopez, 1977).

Available literature on the quality of higher education in the Philippines have dealt with issues ranging from professional examination results to internal aspects of inputs i.e. accreditation, student intake, basic infrastructure, qualifications of teaching faculty, etc.

Accreditation is voluntary in the Philippines and has a positive effect on the quality of higher education in terms of its effectiveness in stimulating institutional improvement. The accreditation is more focused on the programs and not on the institution as whole. There are three different agencies doing accreditation for private institutions. If we analyse the number of accredited institutions in terms of the number of private institutions and the number of programs being offered by these private institutions, the situation cannot be thought as appreciable.

One of the widely accepted measures of quality in the Philippines has been the performance of individuals in the professional board examinations (PBE) conducted by the Professional Regulation Commission (PRC). The annual national average passing rate in the PBE from 1995 until 2003 has been between 41 to 49 percent. Another striking feature is the extreme variation in the results across programs. Although the University of the Philippines-Diliman tops the list of high performing institutions, there are many more high performing private institutions ${ }^{14}$ than government owned institutions (Asuzano and Thomsan, 2001). But the private non-sectarian institutions show the poorest results in the professional board examinations.

The inputs are also an important indicator of quality and these include student intake, faculty qualification and instructional facilities including library holdings. The type of student intake also determines the output of the quality. The best students prefer to go to the most selective and reputed private institutions and public institutions (especially the UP system). The non-sectarian schools are more open, admit more students and charge relatively less tuition than the other prestigious private institutions - leading to a trade off between the quality and student flows. The data on faculty educational qualification reveal that there is much disparity among the faculty across regions. The faculty in Metro Manila institutions hold higher degrees. The low salaries and higher workload in majority of the private institutions do not make it attractive for them to acquire advanced degrees and to engage in research. Inspite of this many reputed private sectarian institutions and a few non-sectarian ones are moving towards substantial improvement in faculty qualifications. 
The instructional facilities are also an important indicator that influences the output quality. The library acquisitions are one of the major features of this. It is observed that majority of the private institutions are in deplorable conditions in terms of library facilities and have low utilization rates of books.

Quality is an aspect which needs to be addressed through a proper strategic framework. The role of CHED in this respect shall remain vital, being the only agency that can partially influence the system.

\section{Lessons learned from the Indian Higher Education System}

At present, India has about 304 universities, including 62 Deemed Universities ${ }^{15}$, 11 open universities, and 15,000 colleges, incorporating approximately 10 million students and 0.5 million teachers. This makes it the second largest higher education system in the world. The overall expansion over a period of time has been appreciable, with student enrolment growing at 5 percent annually over the past two decades. In spite of all this increase in enrolment, only 7.2 percent of the population in age group 17 to 23 constitute the participating group.

The private sector in Indian education has a different magnitude of funding assistance ${ }^{16}$. In fact, one may arrive at an unacceptable conclusion that India has a big private sector involvement in higher education.

India has a long history of private institutions subsequently getting attached to the state ${ }^{17}$. Reliance on state for resources has almost doubled, i.e., from 49 percent in the beginning of the fifth decade to about 84 percent in the beginning of the last decade of the $20^{\text {th }}$ century. On the other hand, the contribution of non-state funding resources has declined drastically.

The structural adjustment policies, which envisaged macro economic stabilization and adjustment, led to a reduction in public expenditures and the introduction of cost recovery measures, accompanied by policy measures toward the 'direct privatisation of higher education' (Tilak, 2001). The new economic reforms and the policy of government is currently encouraging augmentation of resources, exacerbating cost recovery on a larger scale. The fear expressed by many economists/educationalists is that with privatisation, the justification for government funding ${ }^{18}$ would be hit hard but this statement can be considered too early. The public sector system, which has been built over a long period of time, will not fall down suddenly. The role of the government in funding shall remain. There has already been large-scale investment by the government, so the fear that private investment alone in higher education would be socially suboptimal does substantiate in the case of India ${ }^{19}$. Although many committees (UGC 1997, 1999 \& 2000) and reports (Srivatava and Sen, 1997; Ambani and Birla, 2001) have called for cost recovery and reforms, the road to it is still imprecise. 
Although many private institutions across states/provinces have been established, the path towards privatisation still remains unclear in terms of policy framework, this in spite of the interest of the government. No precise policy seems to have been implemented to encourage, regulate and monitor the private higher education system.

The private higher education sector in India will take place on a larger scale in the coming years, in absence of sufficient resources to even sustain the present system, although the expansion of the present public sector system remains a far dream. The government has to acknowledge the need to attract private investment into higher education and the necessity for the private sector to generate financial returns on investments, as has been done in Philippines, but taxing even the sectarian profit seeking institutions in the tax periphery. In order to meet the rising private demand for higher education, the need for sustainable private investment will not take place in the absence of some guarantee of operational autonomy to respond to market demands and a fair return to compensate for opportunity costs and market risks.

The presence of higher quality private institutions would increase the participation of higher income groups in private, fee paying education, thus reducing the subsidy by the non-users (lower incomes) to the users (higher incomes). The savings of the government can be redirected towards extending opportunities.

The expansion of private higher education will require increased government responsibility, especially in providing legislative and policy frameworks for the establishment and operation of private higher education institutions, quality assurance, monitoring and accreditation. In order to emphasize the quality aspect, more agencies should be formed which could accredit individual programs rather than just the whole institution. The accreditation should be made mandatory instead of being optional.

In considering the issue of equity, a fixed percentage of seats can be subsidized with regard to tuition and other fees along with some living allowance for students from disadvantaged socioeconomic backgrounds ${ }^{20}$, and it should be noted that it should not alter the quality balance of inputs drastically which may lead to wastage or discrimination. Even government could partially add to this by extending assistance.

The growing financial constraints on educational investments combined with strong private demand for higher education should encourage reforms in public universities in terms of increasing the share of financial support provided by individuals and their families rather than subsidising all students, and also recognising the future role of the private sector in the policy frame of the government.

\section{Conclusion}


An insight into the negative features of private higher education system throws light on quality disparity, inequality, overloaded faculties, lack of research etc. But this system has its own very strong successes. The private education institutions have been able to fulfil the private demand for higher education, in the absence of the capacity of the state to do so. It is these institutions that have made higher education accessible. The existence of a high number of private institutions and high enrolment in private sector has been able to save public resources. On the other hand, the Indian higher education is facing a financial crisis. The government is not in a position to even sustain the present system, although expansion remains a dream. Because of growing private demand and in the absence of sufficient resources, the role of the private sector has to be recognised by the government while including profit as an objective of their entrance and existence. It is here where many positive features of the private higher education of the Philippines can be replicated owing to its long experience.

\section{Notes}

\footnotetext{
${ }^{1}$ Just 10 years of schooling in the Philippines makes a student eligible for college education instead of 12 years as in most of the countries in the world. This means that the average age of students entering college is 16 years.

${ }^{2}$ Religious groups or orders run the sectarian institutions. In the Catholic sector there are many institutions managed by Jesuits, Dominicans, Recollects, Augustinians, Oblates, and other religious orders. In comparison, there are fewer institutions run by various protestant missions, but they are in significant numbers considering that Protestants constitute less than ten percent of the population.

The proprietary (also known as non-sectarian) institutions are organized as stock or non-stock corporations. Some of them are family enterprises. A few of the stock corporations have been converted to non-stock.

3 The great Filipino leaders and educators include Mariano F.Jhocson, Leon Ma Guerrero, Ignacio Villamor, Felipe Calderon, Jose Albert, Enrique Mendiola, Arsenio Herrera, Maximo Paterno, Dr.Trinidad H.Pardo de Tavera, Father Magsalin and M.Zaragoza.

${ }^{4}$ Colegio Filipino 1900 (National University, 1921) Colegio Escolar in 1907 (University, 1930), the Institute de Manila (University, 1921) Institute of Accountancy 1928 (Far Eastern University, 1934), Mapua Institute of Technology 1925. Some of the established institutions were owned and controlled by one individual or family.

Private initiatives were also made by Americans with the establishment of two universities; Silliman University 1901 (University, 1935), Central Philippine University 1905 (University, 1953)

${ }^{5}$ In 1946, Dalupan organised the Philippine College of Commerce and Business Administration (now University of East), the Southwestern University in Cebu by Dr. Matias Anzar, the University of Mindanao, in Davao City by Dr. Guillermo Torres. In 1947, Dr. Leoncio B.Monzon established Manuel L.Quezon University, the University of Iloilo by Fernando Lopez. In 1948, Fernando Bautista founded Baguio Tech (now University of Baguio). In 1949, The University of Nueva Caceres by Jaime Hernandez, and Foundation University in Dumaguete City by Vicente G. Sinco.

${ }^{6}$ This means that many near poor remain vulnerable to slipping into poverty with only a modest reduction in their income. The official poverty estimates, using income-based poverty lines that are substantially higher than the needs-based poverty lines, indicate somewhat larger increase in poverty incidence, from 36.8 of the population in 1997 to 40.0 percent in 2000 . The FIES 2003 shows little improvement.

${ }^{7}$ Selected institutions are planning to increase the number of scholarships and access on the basis of geographical criteria and school background too.

${ }^{8}$ The internal efficiency of education refers to the relationship between inputs and outputs within the educational institution, and is measured in terms of internal institutional objectives. The external efficiency of education refers to level of attainment of social
} 
objectives, measured in terms of balance between social costs and benefits, or the level to which it fulfils manpower and employment needs.

An important aspect of efficiency i.e. the results of professional board examination has been discussed under aspects of quality because of overlapping.

${ }^{9}$ Investments should produce skills that have economic value beyond intrinsic merit, and the quantity in which it is produced is also important. See Tan \& Mingat 1992

${ }^{10}$ The demand for nurses in the U.S. has increased so nursing courses are offered by most of the private universities and colleges with relatively high fees (in comparison with other courses). Even doctors are now taking nursing courses.

${ }^{11}$ For evaluation of investment from society's objectives viewpoint, social rate of returns are considered. For evaluating the benefits captured by individuals', the private rate of return is considered.

12 There is also an argument that higher education estimates are understated since survey estimates do not take into account individuals who work abroad and earn relatively more, and who are also likely to decide to undertake further education, which extends them an opportunity to work abroad. See Alonzo 1995.

${ }^{13}$ These are University of Philippines, and other sectarian institutions (Ateneo De Manila, De La Salle University and University of Santo Tomas).

${ }^{14}$ Theses institutions are University of Santo Tomas, St. Louis University, Silliman University, Mapua Institute of Technology, Ateneo de Davao University, De La Salle University-Manila and Ateneo de Manila University.

${ }^{15}$ Under section 3 of UGC Act (2000), deemed universities are required to possess viability and a management capable of contributing to university ideas and traditions.

16 The private institutions consist of private aided and private unaided. Private aided are those that receive regular funding for their recurring expenses including salaries of the employees from the state. Many have received funding for capital expenditure and many are getting this assistance in the current scenario too. Private unaided do not receive any grant from state and they consist of both private unaided (unrecognised) and private unaided (recognised). See Tilak 2003.

This paper reflects on private unaided as 'Private' in its discourse and for all arguments related to private higher education institutions in India.

${ }^{17}$ Aligarh Muslim University, Banaras Hindu University, Jamia Millia are some of those institutions which have been founded with the philanthropy of enduring trusts and foundations. Now these are federal universities with complete dependence on federal government for funding.

${ }^{18}$ The three arguments are: (a) higher education investments generate external benefits important for economic development, (b) private investment alone in higher education would be socially sub-optimal and, (c) the issue of equity and access in context of disadvantaged groups. See George Psacharopoulos 1987.

19 The argument of sub-optimal investment in higher education by private sector could be justified only for the newly independent or natural calamities or war effected nations like Afghanistan or Iraq.

${ }^{20}$ Rather than following the policy of quota system, the policy of subsidized provision should be extended to deserving students only as the case exists in Philippines.

\section{References}

Ahamad, B. and M.Blaug. 1973. The Practice of Manpower planning Forecasting: A Collection of Case Studies. Amsterdam: Elsevier.

Ambani, M. and K. Birla. 2001. Report on a Policy Framework for Reforms in Education. New Delhi: Government of India. 
Arcelo, Adriano A. 2001. Graduate Tracer Studies. In Higher Education Research Papers. Pasig City: CHED.

Asuzano, Leticia and Peter Thomson. 2001. Professional Board Examinations in Higher Education. Manila: Asian Development Bank.

Balmores, Nestor. 1990. "The Quality of Higher in the Philippines.” Philippine Education: Promise and Performance. Quezon City: University of Philippines CIDS.

Bazaco, Evergisto O.P. 1939. History of Education in the Philippines, Vol. I, Manila: University of Santo Tomas.

Haas Business School. 1998. The Philippine Student Loan Market Study. Berkeley: University of California.

Hauptman, Arthur M. 2001. Student Financial Aid in Philippine Higher Education: A Framework for Reform. Individual Technical Report. Manila: Asian Development Bank.

Hayden, Joseph R. 1942. The Philippine: A Study in National Development. New York: The Macmillan Co.

Isidro, Antonio and Maximo Ramos. 1973. Private Colleges and Universities in the Philippines. Quezon City: Alemar Phoenix.

Jolly, R. and Colclough. "African Manpower Plans: An Evaluation.” International Labour Review 106, nos. 2-3 (August-september), 1972.

Lopez Salvador P. “Relevance and Quality on Education.” FAPE Review, 7(4), n.d.

Maglen, Leo and Rosario Manasan. 1998. Education Costs and Financing in the Philippines. Technical Background Paper No.2 Manila:. Asian Development Bank.

Paqueo, V and J.P.Tan. “The Economic Returns to Education in Philippines.” International Journal of Educational Development 9(3), 1989.

Psacharopoulos, G and H.Patrinos. 2002. Returns to Investment in Education: A Further Update. World Bank Policy Research Working Paper no. 2881. Washington, D.C.: World Bank. 
Orbeta, A. 2001. Education, Labour Market and Development: A Review of the Trends and Issues in the Past 25 Years. Symposium Series on Perspective Papers for the $25^{\text {th }}$ Anniversary of the Philippine Institute for Development Studies.

Snodgrass, D. and D. Sen. Manpower Planning Analysis in Developing Countries: The State of Art. Development Discussion Paper no.64. Cambridge, Mass:Harvard Institute of International Development, 1979.

Srivastava, D.K. and Tapas K.Sen. 1997. Government Subsidies in India. New Delhi: National Institute of Public Finance and Policy.

Smolicz, J J. Privatization in Higher Education: Emerging Commonalities and Diverse Educational Perspectives in the Philippines, Australia, Poland and Iran. Unpublished Paper, 2002.

Tan, Edita. The Efficiency of the Philippine Higher Education System, Technical Paper No.1. In CHED Task Force on Higher Education. 1995.

Tilak, J.B.G. "Education and Globalisation: The Changing Concerns in Economics of Indian Education”, Editorial, Perspectives in Education, Vol. 17, Special Issue. 2001.

UGC. Annual Report. New Delhi: University Grants Commission, 2001-02.

UGC. Report of the Pylee Committee on the Recommendations of the Punnayya Committee Relating to Unit Cost of Higher Education and Other. New Delhi: University Grants Commission, 1997.

UGC. Report of the Expert Committee Appointed by the University Grants Commission to Review the Maintenance Grants Norms for Delhi Colleges. New Delhi: University Grants Commission, 1999.

UGC. Report of the Committee Constituted by UGC for Formulation of Revised Fee Structure in the Central and Deemed Universities in India. New Delhi: University Grants Commission, 2000. Valisno, Mona Dumlao. ed. The Reform and Development of Higher Education in Philippines. Manila: UNESCO, 2000 